diseases includes " any infection of the udde or teats which is likely to convey disease," and thus applies to infection with $B$. abortus -I am, etc.

M. J. Pleydell.

Health Department, Oxfordshire County Council, Oxford.

SIR,-Dr. R. J. Henderson (29 November, p.550) states that the sale of brucellainfected cows in the open market is increasing. Most farmers entering the voluntary accredited herd scheme in Renfrewshire have not been the raw milk producers, who form a substantial minority. If this is a national tendency, and sale of infected animals is increasing, then human milk-borne and occupational infections will show a tendency to increase in dairy farming counties.

Last year two general practitioners in this county discovered six human cases of acute brucellosis in their practice within a twomonth period. The farm implicated by public health investigators had 16 of 42 cows excreting Br. abortus. There had been no ring test reactors in the herd a year or so previous to this, and the farmer had only purchased two "in-calf" heifers in the interim. One had aborted and been slaughtered, the other had calved normally and been integrated into the dairy herdproducing "standard" milk.

We keep the Ministry veterinary inspectors informed of any brucella-infected animals found during local health authority surveillance of "Premium" and "Standard" milk producing herds. An open meeting with the local farmers was convened by the veterinary authorities to enlist co-operation for the scheme which is expensive to enter (for example, double fencing) and it is to the farmers' credit that most animals found infected in this area are slaughtered. If a known infected animal is moved from this county the appropriate public health authority is notified. There has been no public health surveillance of pasteurized milk producing herds in this county, in the context of brucella infection, as we felt this was essentially a veterinary problem.

Our veterinary colleagues have been given a most difficult task with little financial support. I endorse the view expressed in your leading article (29 November, p.512) that more stringent measures should be introduced to stop the spreading of this disease. - I am, etc.,

Paisley, Renfrews.

F. E. RUSSELl.

\section{Fracture of Curette}

SIR,-Accidental fracture is reported of the curette used for termination of pregnancy by the Kerslake uterine aspiratory method. The method and apparatus used was that described by Kerslake and Casey. ${ }^{1}$ The operator had considerable experience of this method for terminating pregnancy.

The patient, a primigravida, had a normal pregnancy of 12 weeks' gestation. General an aesthesia was used and $0.5 \mathrm{mg}$. ergometrine was injected intravenously before the termination was attempted; paracervical block anaesthesia was not used. The cervix was dilated with Hegar's dilators to number 13 . A $12-\mathrm{mm}$. curette was then inserted into the uterus and moved up was down and to face successively all aspects of and uterus. The conceptus was seen to pass down the curette. No unusual force was used. On removal of the curette its end was found to have fractured inside the uterus. The end was retrieved with some difficulty by the use of retrieved with some difficulty by the use of
ovum forceps; and one was reminded of older ovum forceps; and one was reminded of older
methods of termination of pregnancy when methods of termination of pregnancy when
search for the "foetal head" often proved to be a difficult procedure. The patient made an uneventful recovery.

Inquiry revealed that the sterilization procedure of the curettes was as recommended by the manufacturers-that is, two minutes' immersion in a $\frac{1}{2} \%$ solution of chlorhexidine in $70 \%$ alcohol prior to use.

I wish to thank Peacocks (Surgical and Med ical Equipment) Ltd., Clavering Place, Newcastle 1, who manufacture the Kerslake apparatus, for helpful advice on methods of sterilization of the apparatus. I wish to also thank Professor A. C. Turnbull for permission to report this case. -I am, etc.,

\section{J. M. MCGARRY.} REFERENCE 1 Kerslake, D., and Casey, D., Obstetrics and
Gynecology, 1967, 30, 35.

\section{Leptospirosis}

SIR,-Cases of leptospirosis reported by laboratories in England and Wales during the 10-year period from 1959 have recently been analysed by the Epidemiological Research Laboratory, Central Public Health Laboratory, Colindale (22 November, p. 505). Of 511 cases 319 were due to $L$. icterohaemorrhagiae, 114 to $L$. canicola, and 78 were ascribed to "others and Type not stated."

During the same 10-year period the Regional Virus Laboratory, Ruchill Hospital, Glasgow, has tested paired sera received from 2,200 patients with aseptic meningitis by complement fixation technique against killed $L$. canicola and $L$. icterohaemorrhagiae antigens. A total of 56 cases of leptospiral aseptic meningitis were detected (Table I); 50 due to $L$. canicola and six to L. icterohaemorrhagiae. The diagnosis in all cases was confirmed by agglutination lysis tests carried out at the bacteriology department, Glasgow Royal Infirmary. There was a preponderance of males in both the canicola and icterohaemorrhagiae infections (Table II), and $24(44.6 \%)$ of the 56 cases were under 15 years of age.

\section{TABLE I.-Leptospiral Aseptic Meningitis}

\begin{tabular}{c|c|c|c} 
& \multicolumn{3}{c}{$(1959-1969)$} \\
\hline Year & $\begin{array}{c}\text { L. } \\
\text { canicola }\end{array}$ & $\begin{array}{c}\text { L. ictero- } \\
\text { haemorrhagiae }\end{array}$ & Total \\
\hline 1959 & 8 & 1 & 9 \\
1960 & 8 & 0 & 8 \\
1961 & 5 & 6 & 5 \\
1962 & 4 & 7 & 4 \\
1963 & 9 & 2 & 9 \\
1964 & 4 & 0 & 2 \\
1965 & 2 & 0 & 1 \\
1966 & 1 & 2 & 5 \\
1968 & 3 & 0 & 3 \\
1969 & 3 & 1 & 4 \\
\hline & 3 & 6 & 56
\end{tabular}

Table II.-Age and Sex of Patients

\begin{tabular}{|c|c|c|c|c|c|c|c|c|c|}
\hline \multirow{2}{*}{ Age (yrs) } & \multicolumn{3}{|c|}{ L. canicola } & \multicolumn{3}{|c|}{ L. icterohaemorrhagiae } & \multicolumn{3}{|c|}{ All Cases } \\
\hline & Male & Female & Total & Male & Female & Total & Male & Female & Total \\
\hline $\begin{array}{l}\text { Under } 15 \\
15-44 \\
45-64 \\
65 \text { or more }\end{array}$ & $\begin{array}{r}10 \\
16 \\
4 \\
1\end{array}$ & $\begin{array}{r}11 \\
8 \\
0 \\
0\end{array}$ & $\begin{array}{r}21 \\
24 \\
4 \\
1\end{array}$ & $\begin{array}{l}3 \\
1 \\
0 \\
0\end{array}$ & $\begin{array}{l}0 \\
2 \\
0 \\
0\end{array}$ & $\begin{array}{l}3 \\
3 \\
\mathbf{0} \\
\mathbf{0}\end{array}$ & $\begin{array}{r}13 \\
17 \\
4 \\
1\end{array}$ & $\begin{array}{r}11 \\
10 \\
0 \\
0\end{array}$ & $\begin{array}{r}24 \\
27 \\
4 \\
1\end{array}$ \\
\hline Total & 31 & 19 & 50 & 4 & 2 & 6 & 35 & 21 & 56 \\
\hline
\end{tabular}

The diagnosis of many of these 56 cases would have been missed if these screening complement fixation tests for leptospirosis of interest that during the same period as one Scottish laboratory diagnosed 50 cases of aseptic meningitis due to $L$. canicola the total number of all types of canicola infection diagnosed from all laboratories in England and Wales was only 114 . This suggests that many cases of canicola aseptic meningitis were being missed in England and Wales. These findings support our previous claim that in testing sera from cases of aseptic meningitis killed leptospiral complement fixation antigens, particularly $L$. canicola (which will also detect icterohaemorrhagiae infections) may usefully be included among the battery of complement fixation antigens. ${ }^{1}$

Scotland also appears to differ from England and Wales in that very few human icterohaemorrhagiae infections of any kind have been detected in Scotland within recent years. $^{2}$ It would seem that Scotland has a good Pied Piper.-We are, etc.,

Constance A. C. Ross.

Regional Virus Laborato Ruchill Hospital,

J. C. J. Ives.

Bacteriology Department, Royal Infirmary,

REFERENCES

Ross, C. A. C., and Ives, J. C. J., Lancet, 1960 2, 1278. J. H., and Michna, S. W., British Medical fournal, 1966, 2, 336 Infections

SIR,-I would like to endorse wholeheartedly the views expressed by Dr. A. F Foster-Carter (13 December, p. 685) concerning the use of standard "courses" of antibacterial drugs for the treatment of respiratory infections. Indeed, the point he makes, that the duration of treatment must be judged by the response of the patient, obviously applies equally to chemotherapy of any infection, although for some reason not wholly clear exacerbations of infection in chronic bronchitis seem to have become prey to the cult of the set "course" more than have infections elsewhere.

A possible explanation lies in the failure of many physicians to appreciate that control of bacterial infection in the bronchi is accompanied by disappearance of pus from the sputum, and that macroscopic assesis ment of sputum purulence is the only method by which the need for further chemotherapy can be gauged objectively. To ignore this fact, and to rely upon the nop ient's subjective impressions, will inevitably lead to lack of precision in antibacterial treatment, and, since most bronchitics with days in bed, with an antibiotic thrown in for had not been routinely employed. It seems

\section{"Five-day Courses" and Respiratory} acute exacerbations "feel better" after a few 